\title{
肺結核症と脂肪肝に就的て
}

\author{
長崎大学医学部筬島内科 \\ 祴島 四郎, 井上 満治, 森光 正行 \\ 綿田 紀孝, 井上 章, 諸熊修
}

\section{STUDY ON FATTY LIVER IN PULMONARY TUBERCULOSIS}

\section{BY}

\section{Sirō Osajima, Mitsuji Inoue, Masayuki Morimitsu, Noritaka Watada,} Akira Inoue, Osamu Morokuma

\begin{abstract}
Second Department of Internal Medicine, Nagasaki University School of Medicine, Nagasaki.
\end{abstract}
(Prof.: Sirō Osajima)

\begin{abstract}
梗概 肺結核症と脂肝の関係は，古くから注目己れていたが，近年，肝生検等の応用から，高い頻度 で肺結核症に脂肝が発生することが報告されている。我从は，肺結核症に頻発する脂肝の発生機序学 らかがうことは, 肺結核症の脂質代毁乙関連して重要な課題であると考え, 肺結核患者血清及び, 結

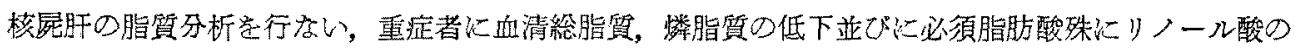
著明次減少空認めた。加結核屍肝脂質分析により，燐脂質の減少，沃度価の低下，酸価の著明な上 昇等の所見から，肺結核症化扝ける脂肝発生について考察した。
\end{abstract}

\section{緒言}

結核患者に脂旰の発生を見ることは古くより知 られている処である。近年勝木，中原り等は䀒生 検により肺結核羅患中の㭧者の脂旰発生頻度を䀒 機轮検查と併行して考察を加え，脂肝のあるもの

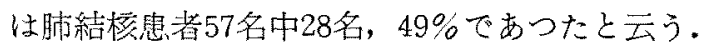
この频度は必ずしも肺結裋患者総へててにあてはま るものではないと考えられるが，かなり頻発する ことが想像される。これ等の患者に肝機能検查を 併行して試み，脂旰を認めたもの〉うち，B.S.P.

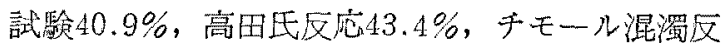
応 $14.2 \%$ ，尿ウロビリノーゲン区応 $35 \%$ に陽性で あつたと云う。結核症において出現する䁕旰は重 症者になる程多くなり，及多くの研究者達の畈機 能换查の成續も重症者に著しく低下例方墫えて来 ることを認めている。
さて，結湌症に高い頻度で出現する脂旰は如何 なる理由によるか，又その機序はどうかと云うこ とは，肺結㮠症の脂質代謝とも関連して重要な問 題であると考えられる。

私共は肺結核患者血清についてまず脂質の分析 を行ない，更にあまり報告されていない肺結核患 者屍旰の脂肪分析を行なつたので，その結果に就 いて報告すると同時に，肺結核症に見られる脂旰 の発生について考察を加えて見たいと思う。

\section{实験及び結果}

結核患者は本学入院患者及び国立長崎療荃所に 入所中の患者的 170名を対象に選び，結校屋旰は 本学病理学教室及 より提供された例について分析した。

採血は早朝空腹時に行存い, 施行中の化学療法 はそのま〉継続させた。 
血清脂質の分析は次の如く行なつた。

総脂質は湜濁法, 総コレステロールは楖沢法, 脂貨的は Allen 法，必須脂酸は Schrade の法 によつた。㕛必須脂酸测定を行なつた数十例は総 脂質を重量法で測定した。

尼旰の脂質分析は湿量測定後，ホモゲナイズし て Bloor 法により 3 時間脂肪抽出を行ない，残 渣を更に 6 時間クロロホルムで抽出, 前者と合し て減圧下に $\mathrm{N}_{2}$ ガスを通じて洒縮した後，残渣を 石油エーテルで抽出した。石油エーテル抽出液 は $0.25 \mathrm{M}, \mathrm{MgCl}_{2}$ の同量で振灏して蛋白質を除 き，遠心して上清を取る，下濖の $\mathrm{MgCl}_{2}$ 層に更 に少量の石油エーテルを加え振盪し, 再び石油エ ーテル層を遠心して取り，前の石油エーテル抽出 液に合し，この石油エーテル抽出液を分割して䋓 脂質, 総コレステロール, 脂質烧, 沃度価, 酸価 等の測定を試みた。なお居盰测定に供した例は死 亡した結核患者より選択的に選んだのではなく， 昭和31年12月より昭和 32 年 6 月迄に剖検された例 を用いた。なお昭和29年1月より昭和31年11月迄 に死亡したホルマリン固定屋旰についても，同様 屍旰脂質の分析を行なつた。

1）血清総脂質（表 1 ）

進展度別分類； N.T.A., 分類に從い軽症, 中等症，重症に分類すると軽症では一般に高く， 重症例では低い，圷濁法による測定値を重症と軽
症例を統計処理して比較すると $5 \%$ の危険率で有 意性を認めた。

病型別分類；增殖型に比し渗出型，混合型で は何れも低下し $5 \%$ の俈険率で推計学上も有意で ある（表1）。

更に赤沈により高度血沈促進群と軽度促進群を 比較したが，有意な差異を認めなかつた。

Broca 指数による分類；105以下の肥満群 と 105〜115 迄の正常群は大差ないが，115以上 の瘦せた群では一見相違があるようであるが, 120 以上と 105 以下の群を統計処理して比較して見る と，5\%の危険率でも有意性がない。

2）血清謎脂質（表 2)

血清脂資燐を，Allen 法で測定後係数25を乗じ

て血清燐脂質量とした。

進展度分類では大体進展度に徒つて平均值は低 下している。これに統計处置を行なうと重症例と 正常者の間に見られる差異は，5\%の危険率で有 意である.病型分類では混合型, 渗出型は增殖型 に比し低い。

赤沈による分類では高度促進群（赤沈 $61 \mathrm{~mm}$ 以上 降下) は中等度促進群 (31m $60 \mathrm{~mm})$, 正常群に甫 し低下の傾问を認める。

3）血清総コレステロール（表 3）

私共が選んだ症例 175名には老人性結核も多数

Table 1. Average of Serum Total Lipid

\begin{tabular}{|c|c|c|c|c|c|c|c|}
\hline Normal & $420^{m g g r}$ & $\begin{array}{l}\text { Type of } \\
\text { Tbc. lesion }\end{array}$ & & $\begin{array}{l}\text { Erythrocyte } \\
\text { Sed. rate } \\
\end{array}$ & & $\begin{array}{l}\text { Nutritive } \\
\text { Condition }\end{array}$ & \\
\hline $\begin{array}{l}\text { Min. } \\
\text { Case } \\
\end{array}$ & 410 & $\begin{array}{c}\text { Productive } \\
\text { type }\end{array}$ & $393^{m g \%}$ & {$\left[\begin{array}{l}\text { Slightly } \\
\text { Accel.group }\end{array}\right.$} & $390^{m g \%}$ & & \\
\hline $\begin{array}{l}\text { Mod.adv. } \\
\text { Case }\end{array}$ & 375 & $\begin{array}{c}\text { Exudative } \\
\text { type }\end{array}$ & 336 & $\begin{array}{l}\text { Moderately } \\
\text { Accel.group }\end{array}$ & 336 & $\begin{array}{l}\text { Obese } \\
\text { group }\end{array}$ & $\begin{array}{l}m g \% \\
380^{\circ}\end{array}$ \\
\hline $\begin{array}{r}\text { Far adv } \\
\text { Case }\end{array}$ & 332 & $\begin{array}{c}\text { Mixed } \\
\text { type }\end{array}$ & 344 & $\begin{array}{l}\text { Heavily } \\
\text { Accel, group }\end{array}$ & 337 & $\begin{array}{l}\text { Thin } \\
\text { group }\end{array}$ & 344 \\
\hline
\end{tabular}

Table 2. Amount of Serum Lipid Phosphor

\begin{tabular}{|c|c|c|c|c|c|}
\hline Normal & $6.93^{m g \%}$ & $\begin{array}{l}\text { Type of } \\
\text { Tbc. lesion }\end{array}$ & & $\begin{array}{c}\text { Erythrocyte } \\
\text { sed. rate }\end{array}$ & \\
\hline $\begin{array}{l}\text { Mins. } \\
\text { case }\end{array}$ & 6.16 & $\begin{array}{c}\text { Productive } \\
\text { type }\end{array}$ & $\begin{array}{r}m g \% \\
6.04\end{array}$ & $\begin{array}{l}\text { Slightly } \\
\text { Accel. group }\end{array}$ & $\begin{array}{r}m g 90 \\
6.63 \\
\end{array}$ \\
\hline $\begin{array}{c}\text { Mod.adv } \\
\text { case }\end{array}$ & 5.67 & $\begin{array}{c}\text { Exudative } \\
\text { type }\end{array}$ & 4.65 & $\begin{array}{l}\text { Moderately } \\
\text { Aecel group }\end{array}$ & 6.35 \\
\hline $\begin{array}{c}\text { Far. adv. } \\
\text { case }\end{array}$ & 4.73 & $\begin{array}{l}\text { Mixed } \\
\text { type }\end{array}$ & 5.13 & $\begin{array}{l}\text { Heavily } \\
\text { Accel group }\end{array}$ & 4.62 \\
\hline
\end{tabular}

Table 3. Serum Total Cholesterol

\begin{tabular}{|c|c|c|c|c|c|}
\hline Normal & 168 & $\begin{array}{l}\text { Type of } \\
\text { Tbc.lesion }\end{array}$ & & $\begin{array}{l}\text { Erythrocyte } \\
\text { Sed. rate }\end{array}$ & \\
\hline $\begin{array}{l}\text { Min. } \\
\text { Case }\end{array}$ & 170 & $\begin{array}{c}\text { Productive } \\
\text { type }\end{array}$ & $174^{m g \%}$ & $\begin{array}{l}\text { Slightly } \\
\text { Accel.group }\end{array}$ & $170^{m g / m}$ \\
\hline $\begin{array}{c}\text { Mod, adv. } \\
\text { Case }\end{array}$ & 176 & $\begin{array}{r}\text { Exudative } \\
\text { type }\end{array}$ & 154 & $\begin{array}{l}\text { Moderately } \\
\text { Accel group }\end{array}$ & 167 \\
\hline $\begin{array}{c}\text { Far. adv. } \\
\text { Case }\end{array}$ & 151 & $\begin{array}{l}\text { Mixed } \\
\text { type }\end{array}$ & 169 & $\begin{array}{l}\text { Heavily } \\
\text { Accel. gqroup }\end{array}$ & 148 \\
\hline
\end{tabular}


湿在し，高血圧者も含まれていた。それ等の総べ ての症例の平均值について比較するとや〉重症群 に低下の傾向を認めたが，統計上は有意でなかつ た。

病型别，赤沈勋，Broca 指数による分類范試 みたが，何れも大差はなかつた。

更に旰機能别による血清脂質の変化を調べる と, 盰機能障害なき群 (B.S.P. $45^{\prime} 5 \%$ 以下, ル ゴール試験 (十) 以下) と盰機能障害群 (B.S.P. $45^{\prime} 5 \%$ 以上，ルゴール試験（H）以上）では総 脂質, 総コレステロールには差異を認めなかつた が，血清燐脂質量は障害群で明らかに低下を示 し，統計処理すると5\%の危険率で有意であつた (表4).

\section{4）血清中必須脂酸量}

表 5 に示す如く，進屡度別に結楆㭧者を分類す

Table 4. Changes of Serum Lipid Phosphor and Total Cholesterol Classified in degree of Liver Function

\begin{tabular}{|c|c|c|}
\hline & Lipid Phosphor & Total Cholesterol \\
\hline Normal & $6.93^{\mathrm{mg} \%}$ & $168 \mathrm{mg \%}$ \\
\hline $\begin{array}{l}\text { Impaired } \\
\text { liver function (-) }\end{array}$ & 4.90 & 175 \\
\hline $\begin{array}{l}\text { Impaired } \\
\text { liver function (t) }\end{array}$ & 4.13 & 161 \\
\hline
\end{tabular}

Table 5. Amount of Essential Fatty Acid in Serum

\begin{tabular}{|c|c|c|c|c|}
\hline & $\begin{array}{c}\text { Linoleic } \\
\text { acid }\end{array}$ & $\begin{array}{r}\text { Linolenic } \\
\text { acid }\end{array}$ & $\begin{array}{r}\text { Arachidonic } \\
\text { acid }\end{array}$ & Total \\
\hline Normal & $58.1^{\text {mg\% }}$ & $26.7^{m g \%}$ & $11.7^{m 9 \%}$ & $96.5^{\mathrm{mg} \%}$ \\
\hline $\begin{array}{r}\text { Min. } \\
\text { Case }\end{array}$ & 39.0 & 16.8 & 8.5 & 64.3 \\
\hline $\begin{array}{r}\text { Mod. adv. } \\
\text { Case }\end{array}$ & 30.5 & 19.0 & 13.7 & 63.2 \\
\hline $\begin{array}{r}\text { Far.adv. } \\
\text { Case }\end{array}$ & 32.6 & 17.6 & 6.7 & 56.9 \\
\hline
\end{tabular}

Table 6. Changes of Serum Essential Fatty Acid in Tuberculous Patients classified in Age

\begin{tabular}{|c|c|c|c|c|}
\hline Age & & $\begin{array}{c}\text { Linoleic } \\
\text { acid }\end{array}$ & $\begin{array}{c}\text { Linolenic } \\
\text { acid }\end{array}$ & $\begin{array}{c}\text { Arachidomic } \\
\text { acid }\end{array}$ \\
\hline \multirow{2}{*}{$\sim 29$} & Normal & $68.44^{\mathrm{mg} \%}$ & $32.3^{\mathrm{mg} \%}$ & $12.6^{\mathrm{mg} \%}$ \\
\cline { 2 - 5 } & $\begin{array}{c}\text { Pulmonary } \\
\text { Tuberculosis }\end{array}$ & 34.4 & 16.2 & 7.6 \\
\hline 30 & Normal & 52.8 & 23.6 & 11.0 \\
\cline { 2 - 6 }$\sim 49$ & $\begin{array}{c}\text { Pulmonary } \\
\text { Tuberculosis }\end{array}$ & 31.6 & 19.7 & 8.4 \\
\hline 50 & \begin{tabular}{l} 
Normal \\
\multirow{2}{*}{$\sim$}
\end{tabular} & 48.3 & 21.7 & 11.2 \\
\cline { 2 - 6 } & $\begin{array}{l}\text { Pulmonary } \\
\text { Tuberculosis }\end{array}$ & 36.1 & 19.6 & 6.9 \\
\hline
\end{tabular}

ると重䎭になる程低下の傾向あり，健康人に比較 すると明らかに必須脂酸総量の低下を㑇めること が出来る.表 6 は年令別に比較したものであるが， リノール酸の低下が最も强く現われている。殊に 若年者程その傾问が强く，青年男子では健康者平

Table 7. Analysis of Liver Lipid in Corpse (Liver fixed in formalin)

\begin{tabular}{|c|c|c|c|c|c|c|c|}
\hline & Disease & $\operatorname{Total}_{\text {Lipid }}{ }^{*}$ & $\begin{array}{l}\text { Total } \\
\text { Fatty acid }\end{array}$ & Phosphatid & Cholesterol & Acid & Iodine \\
\hline 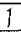 & Pulmonary Tuberculosis & $642 \mathrm{mg}$ & $3831 \mathrm{m9} \%$ & $8.9 \mathrm{mg}$ & $1462 \mathrm{mg} \%$ & 45.92 & 36.5 \\
\hline 2 & " & 1168 & 4014 & $-\quad$ & 1800 & 15.02 & 24.03 \\
\hline 3 & $"$ & 280 & 888 & 12.0 & 1330 & 82.54 & 41.25 \\
\hline 4 & 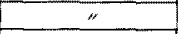 & 238 & 1182 & 5.2 & 1631 & 104.11 & 36.27 \\
\hline 5 & 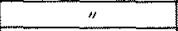 & 276 & 721 & 7.0 & 1420 & 95.13 & 54.24 \\
\hline 6 & $"$ & 174 & 491 & 7.5 & 1332 & 118.27 & 53.25 \\
\hline 7 & 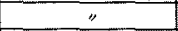 & 288 & $83 \overline{3}$ & 9.0 & 2000 & 92.72 & 17.18 \\
\hline 8 & " & 316 & 1244 & - & 2780 & 54.08 & 42.06 \\
\hline 9 & 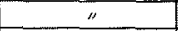 & 280 & 784 & $=$ & 1510 & 46.32 & 44.18 \\
\hline 10 & $n$ & 184 & 528 & $=$ & 1480 & 78.05 & 43.36 \\
\hline II & 7 & 248 & 1013 & $=$ & 1280 & 58.81 & 42.36 \\
\hline 1 & Intestinal Cancep" & 264 & 884 & 200.0 & 7630 & 702.00 & 76.44 \\
\hline 2 & Hypertension & 244 & 851 & 320.0 & 1640 & 103.91 & 76.43 \\
\hline & Hodgkin's disease & 248 & 850 & 4.0 & 1320 & 104.96 & 56.53 \\
\hline 4 & Leukemia & 280 & 949 & 200.0 & 4510 & 95.61 & 161.53 \\
\hline & Cancer of the Uterus & 292 & 921 & 180.0 & 1920 & 99.13 & 54.11 \\
\hline 6 & Accidental death & 260 & 972 & 5.0 & 1320 & 113.92 & 68.58 \\
\hline 7 & Abdominal Tumor & 284 & 904 & 7.0 & 1540 & 94.02 & 75.07 \\
\hline 8 & Senility & 249 & 912 & 190.0 & 1622 & 77.27 & 85.61 \\
\hline
\end{tabular}

* Amount of total lipid per dry weight $2 \mathrm{gm}$ of liver 
Table 8. Analysis of Liver Lipid in Corpse (fresh Liver)

\begin{tabular}{|c|c|c|c|c|c|c|}
\hline & Disease & Total ${ }_{\text {Lipid }}$ * & Phosphatid & Cholesterol & $\begin{array}{l}\text { Acid } \\
\text { Value }\end{array}$ & \begin{tabular}{|c|} 
Iodione \\
Value
\end{tabular} \\
\hline 1 & Nephritis & $4.849 \pi$ & $2.024 \mathrm{gm}$ & $0.206 \mathrm{gm}$ & 59.2 & 121.2 \\
\hline 2 & Progressive Paralysis & 4.56 & 2.875 & 0.340 & 55.4 & 70.4 \\
\hline 3 & Cacinoma of the Lung & 3.93 & 2.530 & 0.360 & 81.7 & 69.1 \\
\hline 4 & Myocardial Infracion & 4.45 & 2.691 & 0.420 & 41.5 & 56.2 \\
\hline 5 & Leukemia & 3.66 & 2.300 & 0.320 & 29.8 & 69.2 \\
\hline 6 & Suicide & 3.91 & 1.971 & 0.380 & 59.5 & 74.6 \\
\hline 1 & Pulmonary Tuberulasis & 4.35 & 1.382 & 0.367 & 78.3 & 42.5 \\
\hline 2 & " & 14.05 & 1.405 & 0.330 & 139.8 & 60.2 \\
\hline 3 & $"$ & 8.06 & 0.967 & 0.328 & 100.0 & 53.8 \\
\hline 4 & 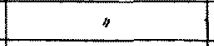 & 4.80 & 2.354 & 0.343 & 173.8 & 46.2 \\
\hline 5 & $\therefore$ & 5.50 & 1.860 & 0.375 & 185.1 & 42.4 \\
\hline
\end{tabular}

* Amount of total lipid per wet weight $100 \mathrm{gm}$ of liver

均値68.4mg\%に対し結核患者では34.4mg\%であ る、刎諭リノレン酸，アラヒドン酸も低下してい る。老人では健康人でも青年に比し著明に低下し ているためか，結核患者々健康人上の間の差異は 若い年令層の如く著明ではなかつた。

5）屡旰脂質の分析

ホルマリン固定䀒における䀒脂質は，表7の如 く，異常に高值を示した2例の他は非結核性疾患 により死亡した例と大差なかつた。総脂酸量は同 様に脂質量の高いものが多く，他に 2 例 $500 \mathrm{mg} / \mathrm{g}$ 以上のものがあつた。この2 例は総脂質量も大体 高徝を示している。燐脂質は全例㱠ど微量であり 比较出来ない，総コレステロール量は総脂質に対 し大体約10〜13\%を占めており，脂旰の强い例で はたら゙その比率が著しく低下している，絶対量で は非結核性のものと結核性のものに大した差異は ない，酸価は一般に非結核性のものよりも結核性 疾患により死亡したものが低い様である。

又 Jod 価も結核性疾患群が明らかに低下して いる.

さらに新鮮屁肝における分析では表8の如く， 非結核性疾患群よりも結核性疾患群においては総 脂質の增加が見られる。

その内訳は総コレステロールは大差ない.しか し燐脂質は結核性疾患群に㧍いて低下を示してお り，殊に総脂質量の增加の著しいものではそうで
古当。

酸仙はホルマリン固定䀒と反対に一般に結核性 疾患群が高い，又 Jod 洒はホルマリン固定旰と 同様酸価と反詨に結核性疾患群の方が低い様であ る.

\section{考察}

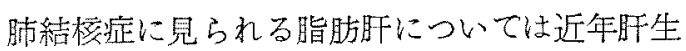
㭘が盛んに行なわれる様になつて以来，多くの報 告が見られる様になつた。 Prinz 等は多数例の 結榿患者に盯生検も実施して詳細な組織学的検討 も加え，又脂肪摄取との関係についても調へててい る、彼等によれば 140例の肺結棪患者中 $19 \%$ に病 的な脂肪浸潤を热めている. 又脂肪浸潤の形成に

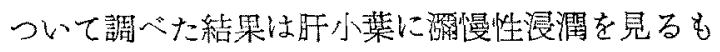
の42\%，中心性39\%，周辺性 $9 \%$ であると云う。 周辺性脂肪浸潤は老袁の如き生理的現象に平行し て現われると云われており，中心性のものは中毒 性のものと一般に云われている. 結椟に䨕慢型が 多いと云うのは，結核がその中間的地位を占める ものであるうと考えられると共に，中心性剆㵎型 の多いのは一考を要する現象であろう，彼等によ れば, 年令, 体重, 肺活量, 病狀, 血清高田反応 等との間に特別の関係は認めなかつたと云う。し かし，勝木，中原等も同様旰生検の結果，57名中 28名 $49 \%$ に脂肪旰を認め，かつ盰機能との間に泌 接な関連のあることを報じている。両者の見解を 
比較するに，勝木は䀒機能が関係すると强調する に反し，Prinz 等はむしろ食䭒性の脂肪旰によ ると强調している．䁕肪旰の出現頻度は病狀の相 違，食䭒の相量により異なることは当然若えられ るが, L.P. Sarin ${ }^{4)}$ 等も䀒生検を行ない100例の 患者中27例 $27 \%$ に脂肪肝を諗めている。私共がホ ルマリン固定䀒について行なつた例でも22例中 5 例は乾燥重量の15\%以上を示し, 又新鮮朋では 5 例中 3 例に脂肪䀒を認めている。更に B. Ban ${ }^{5}$ ) は䀒生榆により他の肺筷患と結核性疾患を比較し て明瞭な差異のあることを報告している。

即与非結核性慢性肺疾㭧33名中 2 例，肺結核症 非治潦群 34 例中 12 例, 治潦群25例中 8 例に脂肪浸 㶄を認めている。

脂肪旰の発生頻度は患者の狀態によつても非常 に相違するのが当然であるが，或るものは殆ど 半数に，或る人は20〜30\%にその発現を認めてい る。しかし他の疾患に比して発現頻度が高いのは B. Ban に限らず大体全ての報告者の諗める所で 西る.その程度については旰生検では確認出来な いが，私共が屁䀒について行なつた例ではホルマ リン固定旰に乾燥重量の58\%，32\%と云う著しく 高い值を示す 2 例があつた。文新鮮旰では最高 14 $\%$ (湿量) で正常䀒の約 4 倍の脂肪含有量であ る.

これ等の例は何れも著明な脂肪旰であり，中韋 性の脂肪旰を箿わすに充分であろう。

脂肪肝の発生について動物笑験により得られた 結果を芫ると生理的と云うが，飢餓その他により 発生する脂肪䀒では一般にその変化が少なく，病 的な変化即ちクロロホルム, 性, 四塩化宸素, 細 菌毒素等の毒物性の場合，或は親脂性物質の久乏 による場合はその変化萃明であるとされてい る. 又飢䬳の場合には一般に hypolipemia が起 こると云われ，Ketosis を伴なうとも良く知ら れている.それに反し病的爿態の結果意起される 脂肪旰ではむしろ hypolipemia と血清燐脂販， 総コレステロールの低下が特長的であるとされて いる.
しからぼ肺結核症に頻発する脂肪肝は如何なる 原因で起こるか二，三の考察を加えて見たい．

先ず血清脂質の変化については笑験 1 から重晸 結核患者程 hypolipemia の傾向を示すことが知 られる。この hypolipemia は全身の栄養狀態 はそれ程関係がない様に思われる。抗結核剂の使 用前の報告は主として重症例の物質代謝異常をそ の栄養不良に执いている様であるが，現在の如～

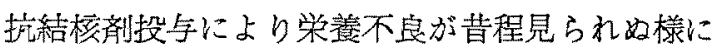
なつても，なおかつ各種の物質代謝異常が見られ ることは栄荃不良のみとは解し難く, 又私共の行 なつた患者 170名についての統計的観察からも栄 養不良と云うことはあまり强調されない様に思 j.

及血清燐脂質の测定を行なつた実験 2 の結果 も，重症者心血清燐脂筫量の低下せる者名多く， 統計的にも有意性を示している。

総コレステロールでは統計上有意性が無かつた が，当教室の古豊は肺結核㭧者中より高令者，高 血圧者を除外して健康人と比較し，明らかに重症 者程有意性があると云う。私共は無差別に患者 を抽出したので有意ではなかつたのであろうと思 j.

旰障害時に血清燐䀝資の低下を見ることは臨床 的にも広く楒められている. 汃る点からもこの 脂肪旰は中毒性の因子が强く関与するものであろ うと考えられる。この点について B.Ban ${ }^{5}$ 等は 結核菌の直接作用，中毒等にその原因を求めて おり，Sarin ${ }^{4)}$ 等は栄養失調及び 新陳代謝障害に 関連した結核の毒力によると述べている。一方多 数例について病理組織的旰脂肪浸潤と食慨摄取 の関係を調べた Prinz 等は, 䀒の脂肪化は可逆 的のものであり食䬣性脂肪の沈着によると述べて いる.しかし結核症に招ける脂肪旰名全て可逆性 の食䬣性脂肪沈着によるかとうかは極めて筑わし い. 私共が屁䀒の脂肪分析を行なつた例の中，特 に3例に著明な脂肪沈着を認めており，之等は可 逆性に变化し得るとは考えられない，むしろ可逆 的な変化をなし得ると云うことは，肺結核症患者 
の脂肪代謝がそれ程まで侵されていないことを示 していると考えたい. 不可逆性の変化が起こる様 になると，荎明な脂肪旰が出現して来るのである う.

こ〉で，もう一つの因子となり得る親脂向性物 質の欠乏によるとする考え方が存在する. 現在迄 動物実験により病的な脂肪旰発生に関係すると考 えられている物質は，多かれ少なかれ大部分のも のが，Cholin と関係のある物䐝である，以下そ れらの物質を挙げて見ると,コリン酸,コリン前駆 幼質，リポカイック，イノシツト，必須脂肪酸等 6)であり，之等の物質の欠圭により起こることが 確認されている. 又 V.B 撕取の異常, 䀒臟投与 等の他, 内分泌系の異常によるものがある7、例 えばインスリン，下垂体前葉ホルモン，成長ホル モン，副謷安質ホルモン，性ホルモン，甲狀腺ホ ルモン等の投与により脂肪䀒の発生を見ることが 報じられている、之等の動物実験による脂肪䀒発 生は動物の種類，動物の年令的差異も非常に大き な関連を有する事がみられている8．

之等の因子久久による脂肪肝発生がとトにおい て必しも発生すると云う訳ではないが，結核患者 血清中の必須脂肪酸量は正常人に比し変化がない かどうか，又あるとすればその程度は如何かと云 うことを調へてみた。詳細については近く著者の 一人井上章が報告の予定であるが，実験 4による と明らかに血清中必須脂肪酸は低下しているのが 判る. その程度は健康老人と大体同程度かや>低 い位である。殊にリノール酸の低下が著明であ る.老人が必しも脂肪旰を来たす訳ではないのて 吻論結核における脂肪肝が，迎清中必須脂肪酸の 低下と直接関連するとは考えない。しかし䀒脂肪 の分析を行なつた実戨 5 の結果を茪ると，肝脂質 中の憐脂質含量，ヨード価が他の原因で死亡した 例のそれに比し明ら加に低下していることも必須 脂肪酸の代謝不全を思わすに充分であり，血清中 必須脂肪酸の低下と密接な関連を有するものと洘 えられる。

Barnes ${ }^{9)}$ は必須脂肪酸の欠采によりレチチン
の腸粘膜における合成が低下することを見てい

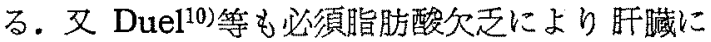
おける䊁脂資の turn over が恐らく減少して脂 肪代謝及び中性脂肪の輸送が障害を受け，脂肪肝 加発生して来るのであるうと述へている。

かっる点を考虑に入れると，肺結核患者で血清 中必須脂肪酸が著明に減少していることは脂肪旰 発生に好都合の条件であることは筑いないところ である。しかし肺結核症に㧍ける血清必須脂肪酸 の低下の原因については今の所不明である。

以上肺結模症の脂肪䀒について述ぺたが，私共 は肺結梌症の脂肪肝に毒性の因子が大心に関係す ること，文食䬣性の因子が存在することは認める が，それは一過性と云うか不可逊性䁕肪䀒一の移 行の段階に見られる現像であると考えている。屁 旰脂韻酸価の著明な上昇之脂肪䀒発生之の間には 密接な関係があるのではないかと思う。酸価の上 早は脂酸代謝の不円滑を示すものであり，又肺結 核症患者に脂肪負荷を行なうと脂肪代謝の不円 滑が起こることは広く認められているところであ る.森光11によれば脂肪負荷動物では肺結核症の 場合，血清中性脂䁈が正常家秋に比し 8 時間後も 著明な高値を示していると云う。このことは盿結 核症で性燐脂質代謝，広く云えば脂肪代謝が円滑 を欠いていることを示すものであると同時に，燐 中毒の如く，完全なコリン合成の停止と云つた强 い変化は起こらないで，緩やかな慢性の中毒性变 化を起こすことによると思われる。

\section{結 論}

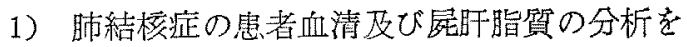
行ない，次の如き結果を得な。

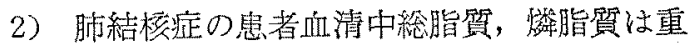
症者に低下の傾向を認める。

3）血清中必須脂肪酸量は肺結核患者では著明 に低下し，殊に量的にはリノール酸の低下が著明 である。

4）結核屁旰の中には正常時の4 倍以上の著明 な脂肪旰を示すむのがあつた。

5）結核尼䀒脂質の分析の結果は碳脂質量の減

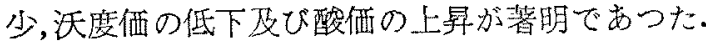


6)肺結核症では脂肪酸代謝障害と脂肪旰発生 の間に密接な関連があるのではないかと思う。

\section{文献}

1) 滕木, 中原, 柳沢, 桑原: 結核, 29, 176 (增 刊号). - 2) W. Schrade, R. Beigler, C, Ott: Klin. Wschr., 34, 1242, 1956. - 3) F. Prinz: Otsch. Med. Wschr., 83, 914, 1958. - 4) L.R. Sarin: Am. Rev. Tuberc., 76, 410, 1957. - 5)
B. Ban: Am. Rev. Tuberc. 72, 71, 1955. - 6) H.J. Deuel: The Lipids II., 639, 1955, Interscience Publishers. - 7) H.J. Deuel: The Lipids II, 684, 1955, Interscience Publishers. - 8) P. Hamdler: Proc. Soc. Exptl.Biol. Med., 70, 1949. - 9) R.H. Barnes, E.S. Miller and G.A. Nurin: Biochem. J., 34, 884, 1940. - 10) H.J. Deuel: The Lipids II., 679, 1955. - 11) 森光正行: 未発表. 